International Journal of Advanced Trends in Computer Science and Engineering

Available Online at http://www.warse.org/IJATCSE/static/pdf/file/ijatcse6091.42020.pdf

https://doi.org/10.30534/ijatcse/2020/6091.42020

\title{
A Review of Service Quality Elements towards the Overlapping IT Framework Process on the IT Hardware Support Services (ITHS)
}

\author{
Azham bin Ahmad ${ }^{1}$, IsmiSafiaAdilabinti Ibrahim ${ }^{2}$, Lukmanulhakim bin $\mathrm{Ngah}^{3}$ \\ ${ }^{1,2,3}$ Faculty of Computer, Media and Technology Management, UC TATI, Malaysia, \\ 1 azham@tatiuc.edu.my \\ 2ismisafia@tatiuc.edu.my \\ ${ }^{3}$ hakim@tatiuc.edu.my
}

\begin{abstract}
Many large organizations use the information technology (IT) service processes to deliver IT services within the service level agreement (SLA). In order to support and expand the business, an organization needs to be able to promise reliable and effective information technology (IT) Service Quality. Nevertheless, each of the IT frameworks has many components and processes. This is difficult for the organization as it involves management commitment, complicated process diagrams, general work instructions, it does not assign process owners, and concentrating too much on performance. It can also be troublesome because it does not include a roadmap or description of key process areas for change, but rather only defines the priorities of each implementing stage. Several of these IT frameworks are not combined and possibly unified to provide such a dominant IT framework developed, especially for IT hardware support services (ITHS). The combination of reliability, assurance, responsiveness, empathy, and tangibles in the IT framework can complement the Service Quality dimension as it enhances the quality of services, especially in the IT hardware support services. This approach is used to measure the IT service department, especially the hardware support services, as it reflects the operational performance of the organization. This study is proposed to assist organizations with multiple frameworks completion constraints by enlightening them the overlapping frameworks before its implementation. This study adopted the design science research (DSR) as its methodology. The objective of this study is to demonstrate and evaluate the proposed ITHS. This study represents a novel and state of the art piece to the body of knowledge. The organization can also apply it to improve its IT services. It is found that the proposed maturity model as complete and useful. Positively, this study enhances the conflicting problem in the structure and suggests that some organization do not realize the real maturity level of their IT system. Researchers can identify and develop a maturity model for multiple application for its current IT systems processes. The findings of this study is strengthened by the creation of a specific maturity overlap that involves the most renowned IT
\end{abstract}

frameworks on the market which improves the way organizations manage the complexity of overlapping frameworks.

Key words :IT Framework, IT Services, Quality, Service Quality

\section{INTRODUCTION}

Information Technology Hardware Support (ITHS) plays a vital part in the supporting, surviving, and growing of most companies through establishment of associated business strategies and new policies. IT services expanded quickly and broadly due to the extreme growth of programs and numerous types of organizations. In contrast, IT Service Managers face challenges to minimize costs while enabling them to produce sales and provide their customers with quick-cost-effective services. ITHS ensures the organization to operate smoothly, especially when dealing with the information technology (IT) incidents. IT incident must be tackled in a specified time as it contributes to the performance of the services in tangible and intangible manners. Processes in ITHS are designed to deliver the services within the service level agreement (SLA) requirements as it influences the quality of the services. Many IT frameworks are suggested to relieve the organization's management of its IT governance. IT frameworks, for example, is perceived as very generic and very intricate.

Despite the importance of frameworks, there are still many raised issues that need to be looked. For example, IT frameworks are considered as very generic and not built for the ITHS environment. Its system and components are deemed as quite complicated. Most of these IT frameworks are not typically exclusive and combined to provide a reliable IT system, but most of them overlap in processes. The combination of reliability, assurance, responsiveness, empathy, and tangibles in the IT framework can complement the Service Quality dimension as it enhances the quality of services, especially in the IT hardware support services. This approach is used to measure the IT service department, especially the hardware support services, as it reflects the operational performance of the organization. More than one hundred dissimilar maturity models have been suggested [1], but most are too general and as a result, are not well defined or documented. 


\section{LITERATURE REVIEW AND RELATED WORK}

This section presentsthe reviews of relevant literature from the aspect of IT services quality onIT hardware support. The tradition of IT supports services cannot be contradicted in every phase of work by individuals, businesses, or organizations. It is a significant activity and needs to be measured from time to timeto certify the advantages of IT services usage.

\subsection{Quality}

Every single product or service ended with quality elements. Quality is the results of the measurement given by the customers, suppliers, vendors, or the internal and external to a product or a service provider. Quality is achieved when a product or service achieves the minimum level of required performance. Quality has different ranges of results. For example, a quality computer system can be the basic computer system provided by either Dell or HP. Once a customer purchases their computer, each provider has a different design of requirements to comply with, and quality to be provided to the customer. Standard is within the recognized spectrum of size, quantity, and strength, while good value refers to higher quality, and suitable for purposes. Quality in this study refers to the Quality of Services (QoS). It is defined as the descriptions of the overall performance of services. For example, providing the IP network is becoming very important in the aspect of today's Information Technology Infrastructure Services (ITIS). Not only does QoS is meant to support the voice and video streaming over the network, but it is also an essential factor in supporting the growing Internet of Things (IoT).

The word quality comes from the Latin word "quails," which could be translated as "what kind"[2]. There are no coincidences, therefore, that the actual meaning and interpretation of the word are so different. According to [3], the value can be defined as "free of defects" in the simplest sense. However, most consumer-centered businesses go beyond simplicity and describe this more accurately as customer satisfaction. [4]claimed that quality is one of the many concepts that are very difficult to explain in the social sciences and can be defined according to five fundamental approaches.[14]described the five basic approaches as the Transcendent approach (subjective and personal), Product-Based Approach (measurable), User-Based Approach (customer satisfaction), Manufacturing Approach (compliance with particular requirements), and Quality-Based Approach (concerning expenditure). The Transcendent Approach refers quality as a product or service excellence based on subjective relation to some standard or specification. It is hard to define this concept because it is not definite that people will like the product. Meanwhile, the Product-Based Approach defines quality as precision and recognition. In contrast, the User-Based Approach refers quality as the products or services that meet the preference and needs of the people, users, and consumers. The Manufacturing Approach defines quality as the degree of excellence that is reflected by the cost and value of the products or services. These approaches have been adapted, refined, and expanded throughout the literature to define quality [15].
Various definitions of quality are used by practitioners and academics, but there is no generally agreed definition about it since each definition of quality is appropriate under different circumstances [5]. Indeed, quality can be defined as excellence [6], value [7], conformance to specifications [8], conformance to requirements [9], fitness for use [10], product desirable attributes [11], loss avoidance [12] and meeting customer expectations [13].

[16] states that "quality" comes in several terms, including quality assurance, quality control, quality management, quality audit, and quality enhancement. It is essential for the term quality to be defined from a different perspective at different descriptions by providing more ample background, as well as the link between the term quality and previously concepts such as marketing, relationship marketing, customer relations management, customer experience management, customer satisfaction, and loyalty.

\subsection{Service Quality}

Service and quality carry two different definitions. Service is the intrinsic characteristics of a given service, while quality is a user-based approach. A dynamic and temporary definition is the consistency of the service. Businesses understand that improving Service Quality is a crucial strategy in today's dynamic economic environment for success and survival. [17]. Currently, Service Quality (SQ) is the most important and widely researched topic in services [18]. SQ represents the majority of today's economy, not only in developed countries but also in developing countries. SQ is a result gathered from customers' comparisons of their expectations and perception about the encountered service [19].

$\mathrm{SQ}$, according to [20], [21], is the result of consumers' comparison of expected service with the services they received. Customers will always be the best judge for the quality of any services. Customers' perceptions will lead to their judgment of the image of the services they received. Defended by Grönroos (1988), Parasuraman et al. (1986), Schneider and White (2004), and Zeithaml (1988) [22],who express their preference for the concept "perceived quality." The work of [23] focuses on Service Quality as the specific dimensions of service that reflects the customers' perception, which is reliability, responsiveness, assurance, empathy, tangible. The appliance repair sector, retail banking, communication service, securities brokerage, and banking are some of the sectors that are currently adopting these five dimensions as their perceived quality. Again, according to [24], determining perceived Service Quality involves the level of comparison of what a customer should expect. Based on the work of[25], measuring satisfaction involves the appropriate comparison of what a customer would expect. Every element of the Service Quality dimension directly relates to human interaction.

According to Parasuraman ,as cited by [22], Service Quality is defined as the "global judgment or attitude relating to the overall excellence or superiority of the service." On the other hand, Service Quality is regarded as an assessment of how well a delivered service conforms to the client or user expectations needs and wants. Reputation is defined as a perception of past actions, and future behaviour is viewed not 
in isolation, but rather in the context of what others are doing in the marketplace [26].

The Five SQ Dimension [21]; [27]; [28] is an instrument that is developed by reducing the ten dimensions into five dimensions[20]. The first dimension, that is, the tangibility dimension, contains the presence of physical facilities, equipment, personnel, and communications materials. The general condition of the physical environment is the tangible proof of care and consideration to details shown by the service department. Meanwhile, the reliability dimension refers to the ability to perform the promised service correctly and without fail. Reliable service performance is the customer's expectation for the service to be completed on time. Reliability has been used to comprehend the competency of the service under various real-world conditions. For instance, a cloud solution with an SLA determination of $99.999 \%$ may be available. In the meantime, the responsiveness dimension refers to the willingness to help clients or users through prompt services. Keeping customers waiting for no discernible reason creates unnecessary misconceptions about the quality of the service. Throughout the event of a service failure or interruption, the ability of the service provider to recover quickly with professionalism can lead to very positive perceptions of quality assurance, which is expressed through the knowledge, kindness, and skills of the customer service staff. In contrast, the assurance dimension comprises the expertise of the service provider to perform the services in a kindly, dignified manner, communicatively, and in the best interest of the customer. Finally, the empathy dimension is the provision of care proven by the customer service staff and the individualised attention given to the customers. Empathy includes accessibility, a sense of security, and the effort to help the needs of the customer. SQ brings the credibility of an organisation, and the level of quality given often defines the customers' view towards the organisation, which may result in the improvement or deterioration of its credibility. Satisfaction, on the other hand, is influenced by customers' perceptions of the product and Service Quality, based on personal factors, and price as well as situational factors, which is more inclusive. [29] states that the term "quality assurance" is complex, and its different angles of viewpoints are often challenged.

According to [3], quality in its most basic form can be defined as "freedom from defects."Many organizations used this simplistic view for most centric cons umers and are described as customer loyalty, a more suitable term. Commencing [30] is a significant value and has a variety of meanings in the context of "service."Its crafted challenges draws to the viewpoint of SQ. Again, [31] label SQ as a general judgment approaches to the service supremacy, but admits that exact nature is still vague and needs to be investigated further. [32]defines SQ by stating that it is an attitudinal type, which is related to customer satisfaction, but not equal to it.

\subsection{IT Services}

IT services signify the use of hardware, software, and supporting infrastructure to manage and deliver information or an organization's operations, functions, and services to the user. IT services offer responses to specific information processing requirements and are configured into heterogeneous portfolios of information processing capabilities [33]. An IT service provider also provides one or more customers. IT services are based on the use of IT to support or enable business processes [34]. A company or organization that is structured by IT processes has found to improve its business performance effectively[35]. The effectiveness of IT services has become increasingly crucial to any organization. Analysing the effectiveness of IT service components is also becoming increasingly important [35]. In order to meet the increasing users, organizations need to allocate higher investments in IT. However, the measures generally analyse IT effectiveness based on products rather than on services. Thus, this provides inconsistent information for decision-making [36]-[38].

A service is defined as a time perishable, intangible experience performed for a customer acting in the role of a co-producer. Service measurement plays a vital role in Information Technology Service Management (ITSM), one of the sub-fields of services computing science. Many IT service organizations consider the measurement of ITSM processes, especially service support processes, as a difficult task due to the following four reasons: (1) IT organizations do not have a structured approach to measure IT services and service management processes, (2) tools used by service support teams do not enable effective measurement, (3) ITSM standards and frameworks do not provide practical examples as to how to measure support processes, (4) too many options used to measure service management [39].

Internal IT Service Quality refers to the support and services provided by the IT department and outsourced IT vendors to the system users. The IT department is meant to provide better customer service and intensify the profit and growth of a company. Hence, managing internal IT Service Quality is extremely important [40]. In the users' perspective, the IT department is meant to assist them in a variety of tasks such as IT systems, hardware installation, problem resolution, timely replacement of old systems with new systems, identification of outsourced services, and systems training. Since the IT department is also the provider of services, apart from product, the quality of the IT department's service, as perceived by its users will indirectly affect the performance and profits of the organization.

\subsection{Quality of IT services}

Service Quality (SQ) is an abstract development, elusive and difficult to measure due to three unique features of service delivery. In the first place, service is a non-physical product; it cannot be transported, stored, measured, tested, inventoried, or weighed before it is sold. In the second place, heterogeneity services can vary from one provider to another, from one customer to another, and even from one day to the next, and finally, the inseparability between production and consumption. Services are consumed almost simultaneously with their production, making it difficult to detect and correct imperfections before the client is affected. [21], [41]. In the context of ITHS, the services offered are different from one user to another user, as it is subjective. Respectively, users 
have their perception of Service Quality received from the IT staff. The capability and skills of the IT staff in troubleshooting computer components led to confidence. In contrast, reliable services from the staff led to the performance of the services that reflects the IT operational performance.

The IT services offered to clients directly support the business processes of one or more customers, and its service-level targets defined in an SLA. IT support services, also known as the Information Technology Infrastructure Services (ITIS) is not directly used for the business of the organization but are necessary for the service provider or internal service department to deliver the targeted customer service. ITIS has some peculiarities that set them apart from other services, and evaluation by the user is even more subjective [42]. ITIS is intangible because, although their provision can have a predominantly physical outcome, such as assembling a PC or installing a network connection cable, other existing services are entirely intangible, such updating software on a computer or providing training or helpdesk support (support service for supporting users and solving technical IT problems [43]. These are the skills of the IT staff in performing technical issues in ITIS.

Many Information Technology Infrastructure Services (ITIS) are produced and consumed simultaneously and are influenced by the varying perceptions of different users. For example, while a service provided by a helpdesk is considered useful by a nonprofessional user, the professional user may consider the same service to be slow and bureaucratic. Namely, a poor and unsatisfactory experience with a helpdesk can negatively influence the user's perception of the quality of service and resulted in the customer to decline to receive new services from the provider or at least fostering a reputation of distrust. There is an indication of the need to assess and monitor the quality of the service.

\subsection{Service Quality and Information Technology (IT)}

According to [44], SERVQUAL (SQ) helps IT managers to identify areas that need to improve its Service Quality, as well as to help researchers to discover promising IT service measurements. Several IT studies do not confirm the model factors. [45] and several other studies have identified a different range of factors [36], [46]. Thus, the non-compliance of the SQ element formation in IT studies shows its continuous evaluation in separate IT contexts. [47].

An organisation can control the quality of its IT services by evaluating the extent of compliance by the service delivery with the laid down specifications. Through this approach, researchers can use objective measurement to describe and assess the performance of IT services throughout the companies. By focusing solely on quantifiable measurement, the quality management tasks in IT services include establishing a means of defining quality requirements, correctly translating requirements or assures into requirements or guidelines, monitoring, reporting, and analysing the performance against the specifications by measurement. At least two practical approaches in IT services are required to manage compliance quality. The first approach is used to define the quality of services (QoS) specification language in which quality specifications, quality capabilities, and quality agreements are set out in the SLA. In contrast, the second approach is utilized to qualify the standards of service level. Since Service Quality management is one of the main objectives of service level management (SLM), the components of Quality of Services (QoS) standards originally derived from certain IT management frameworks. In the service Level Management (SLM) section of ITIL, the provided SLA skeleton is convenient to release and track metrics throughout the SLM methods. Closely related details are available in CMMI, SPICE, and CMMI IT Service.[48]-[50].

Based on [51],Service Science is the emerging connectivity of various techniques and methods from different fields related to the understanding, design, improvement, and scaling of service systems. Services Science is a novel approach to viewing, developing, and implementing ICT. Service Science builds on the contexts' service' in the sense of deed, process, performance, by combining people, processes, and technologies that socialise to deliver services. Types of services include supplier and customer interaction; ICT exploitation, change management and transparency. Service Science incorporates many disciplines, including computer science, operations research, industrial engineering, business strategy, management sciences, social and cognitive sciences, and organizational theory. Information Technology Service Management (ITSM) is a branch of Service Science that focuses on IT operations like service delivery and service support. Based on the works of [52], [53] Information Technology Service Management (ITSM) is part of Service Science that centres on IT operations, including service delivery and service support. ITSM is a rigour for maintaining IT operations as a process-oriented operation that accounts for 60 percent to 90 percent of IT maintenance costs. Most of the significant factors connected to Service Science have been discussed in parallel to IT service operations

\subsection{Information Technology (IT) Framework}

Several IT frameworks are shaped to accomplish, appraise, and line up to the IT objectives besides the organizations' goals. A framework may be a standard, a repository, a method, or a model. All Standards and repositories have its version numbers. A standard constructed from a set of requirements, while the repository is specified by a set of recommendations. A method is a set of steps, while a model is a set of tools. Standards and repositories can use one or more methods or models.

In order to sustain and improve business, an organization must be able to guarantee the stability and performance of the information technology (IT) Service Quality. Many IT organizations have started to use frameworks and measurement to monitor, evaluate, and restructure their organizations. Examples of popular frameworks are the Capability Maturity Model (CMMI), Control Objectives for Information and Related Technology (COBIT), plus the Information Technology Infrastructure Library (ITIL). Percentage of incidents resolved by first-line support, the average time to resolve incidents, the percentage of releases on time, and the percentage of IT staff turnover are some of the examples of measurements [54]. 
[55]defines service as an act performed by one entity for another, including the provision of resources that another entity will use. In the context of IT services, an IT service provider provides amenities to one or more customers. IT services are based on the use of IT to support or enable business processes [34]. IT service is sophisticated due to the amount of equipment used, such as the hardware, the operating system software, the application software, and telecommunications network equipment. Continuous developments are needed to manage the exploitation of new technology. Many large companies with IT services used information technology (IT) framework to govern their internal IT services used by other internal departments such as the marketing, human resource, and finance department. According to [56], many IT frameworks are used to govern the IT system according to the organization's business environment, mission, and vision of the company. IT governance represents a structural relationship between different processes and mechanisms through effective and efficient use of IT strategy and resources that coordinated to achieving the goals and objectives of an organization. IT governance has been defined as "the decision rights and accountability framework for encouraging desirable behaviours in the use of IT" [57]-[59]

Meanwhile, [60] state IT governance to include creating an IT strategic plan, assessing the nature and organisational implications of new technologies, developing an IT expertise base, aligning IT direction and resources, safeguarding the interests of domestic and international IT stakeholders and taking into account the quality of interactions between stakeholders. The overall IT framework is being developed to increase IT efficiency, reduce IT costs, and increase control of IT revenue by both government and business agencies. Among these, the most popular models are the ITIL, COBIT, and [61] state ISO17799 standard, which can provide guidance and tools for better IT governance [62].

\section{RESEARCH METHODOLOGY}

The assessment of artefact includes the building and evaluation through the Design Science Address (DSR). The purpose is to identify the business objective need and involve many processes to design the framework process, research contribution, design, evaluation, and finally, communicate the output to the appropriate people [1]. DSR research shapes the "to-be" formation and pursue to form according to the outlined model, captivating the constrain and limitations [63].

DSR is suitably used for research studies that pursue to lengthen the borders of human and organizational abilities besides forming up-to-date artefacts. DSR varies from the previous research theories since it tries to change and develop artefacts that supported operative in real-world circumstances [64]. DSR method involves planning, building, and calculating the developed IT maturity model. [65]claimed that DSR could be practically applied to the open scope of IT-related areas. Undeniably, it is concluded by [66] that DSR is the best research methodology for the analyses of IT governance consisting IT management.
Table 1: Design Science Research Parameters. Adopted from Hevner [65].

\begin{tabular}{|c|c|c|}
\hline Guidelines & Description & Investigation \\
\hline $\begin{array}{l}\text { 1: Design as an } \\
\text { Artefact }\end{array}$ & $\begin{array}{l}\text { Design science } \\
\text { research needs to } \\
\text { develop a viable } \\
\text { object in the form of a } \\
\text { construct, a prototype, } \\
\text { and a technique. }\end{array}$ & $\begin{array}{l}\text { A model is } \\
\text { proposed }\end{array}$ \\
\hline $\begin{array}{l}\text { 2:Problem } \\
\text { Significant }\end{array}$ & $\begin{array}{l}\text { The purpose of design, } \\
\text { scientific research is to } \\
\text { increase } \\
\text { technology-based } \\
\text { solutions or outcomes } \\
\text { into significant and } \\
\text { suitable business } \\
\text { pitfalls. }\end{array}$ & $\begin{array}{l}\text { Framework } \\
\text { overlap and } \\
\text { multi-framework } \\
\text { implementation } \\
\text { exploration. }\end{array}$ \\
\hline $\begin{array}{l}\text { 3:Design } \\
\text { Evaluation }\end{array}$ & $\begin{array}{l}\text { The utility, quality, } \\
\text { and efficacy of the } \\
\text { design object must be } \\
\text { strictly verified } \\
\text { through well-executed } \\
\text { inspection techniques. }\end{array}$ & $\begin{array}{l}\text { Semi-structured } \\
\text { interviews and } \\
\text { conferences. }\end{array}$ \\
\hline $\begin{array}{l}\text { 4:Research } \\
\text { Contributions }\end{array}$ & $\begin{array}{ll}\text { Effective } & \\
\text { design-science } \\
\text { research must } \\
\text { determine clear and } \\
\text { testable selections in } \\
\text { the design } \\
\text { components } \\
\text { artefacts, of } \\
\text { structures, or design } \\
\text { techniques. }\end{array}$ & $\begin{array}{l}\text { A new and unique } \\
\text { artefact, } \\
\text { concerned with } \\
\text { the body of } \\
\text { research. }\end{array}$ \\
\hline $\begin{array}{l}\text { 5:Research } \\
\text { Rigor }\end{array}$ & $\begin{array}{l}\text { Design science } \\
\text { research relies on the } \\
\text { application of required } \\
\text { techniques in the } \\
\text { construction and } \\
\text { assessment of the } \\
\text { artefact design. }\end{array}$ & $\begin{array}{l}\text { Construction: } \\
\text { Becker guidelines } \\
\text { and procedures. } \\
\text { Evaluation: } \\
\text { Semistructured } \\
\text { Interviews }\end{array}$ \\
\hline $\begin{array}{l}\text { 6: Scheme as } \\
\text { Search } \\
\text { Development }\end{array}$ & $\begin{array}{l}\text { The quest for an } \\
\text { efficient artefact } \\
\text { involves the use of } \\
\text { offered means to } \\
\text { achieve the desired } \\
\text { ends while complying } \\
\text { with legislation in the } \\
\text { problematic } \\
\text { environment. }\end{array}$ & $\begin{array}{l}\text { Unknown } \\
\text { outcome. } \\
\text { Combination of } \\
\text { well-known, thus } \\
\text { predefined } \\
\text { frameworks with } \\
\text { significant } \\
\text { techniques. }\end{array}$ \\
\hline $\begin{array}{l}\text { 7: Interaction } \\
\text { of Research } \\
\text { Study }\end{array}$ & \begin{tabular}{l}
\multicolumn{2}{l}{ Design-science } \\
research must be \\
effectively presented \\
for both \\
technology-oriented \\
and \\
management-oriented \\
viewers.
\end{tabular} & $\begin{array}{l}\text { Assessed with } \\
\text { practitioners and } \\
\text { submitted it to a } \\
\text { respectful journal. }\end{array}$ \\
\hline
\end{tabular}


Based on Table 1, the Design Science Research (DSR) for Information Systems (IS) was adopt in order to conduct, and evaluate the information system (IS) research. [65]provides the practice directions for conducting DSR, which is consisted of seven standard guidelines. According to [67], Hevner's guidelines should not remain utilized evenly to all DSR papers, and so they are related dependent on the situation of each research.

\section{NOMINATED IT FRAMEWORK TO THE RESEARCH}

Presently, several IT frameworks are consisted of ITIL, COBIT 5, CMMI, TOGAF, COSO, Six Sigma, VAL IT, and PDCA. Only three IT frameworks were selected (COBIT 5, ITIL, and CMMI - SVC) for this research purpose. The rest of the IT framework deals with the process of the organization culture, investment, fraud deterrence, manufacturing, and project management that tells the overall IT stages plan.

The first framework is the COBIT, which classifies control objectives and IT processes conducted by IT organisations. For each process, COBIT plans a wide range of activities for each IT course of action to enable managers to extend or minimise associated risks, configurations, actions, and strategies. COBIT helps the organisation to realise the importance of positioning its system. This later results to the credential of supervision, governance vital and requisite by the organization to deliver such lessons using maturity models standards of essential expertise enhancements, performance areas, and IT procedures measurement. The measurement used is then measures the processes and maps the organization goals to meet the business requirements and IT position. The component selected from the COBIT process is the Deliver, Service, and Support (DSS). DSS functionality accepts classifying, recording, and prioritizing incidents according to their criticality or urgency. It also carries the flow for completion of each event, in order to define a speedy solution to the problems affecting business or organization continuity. The efficiency of IT service performance enhances the value of the IT service implementation.

Next, is the ITIL, whichincludes records and rules the direction to organize quality performance management. Besides, performance management actions will occur with processes in the scheme of ITIL services and existing conditions [68]. It improves the activity process that focuses on refining and gauging the Service Quality based on business perspectives and users. Only the service operation process was selected for this study. This is because to specify services that are fit, stable, and reliable in IT service support as to reduce downtime and costs while improving customer satisfaction. On the ITIL service process, reliability of IT service support assists vital business functions. This is to ensure the strategy supports the current and future IT service availability requirements of the business or organization needs [69]. Another dimension that reflects the SQ is responsive. Responsive refers to the improvement of IT function and the resolution times to solve the "users" request and problems related to IT service malfunctioning or other service requests. This led to a reduction of incidents and improvement in the responsiveness of internal IT staff.

The final framework is the Capability Maturity Models Services (CMMI SVC). CMMI is intensive on Business Process Management (BPM). BPM is a regulation or instruction in operation management in which people practice various methods such as model, analyse, measure, improve, optimize, and automated business processes. In CMMI SVC, the subject contains twenty-four process areas, where seven areas were service-specific. Only components from the Incident Resolution and Prevention were nominated to signify the present research purpose. The purpose of this process is to ensure timely and effective resolution of service incidents and prevention of service incidents. The process from the component categorized and analysed the incident that reflects the services. It also identifies the action needed for the incident and monitored the status, tracking, and escalating it to the proper level of support services. This process reflects the services. Every organization should have a decent organization, respectable processes, and reliable management systems. All of these portions contributed to provision of excellent services to the users or customers and resulted in positive IT operational performance and profits to the organization. From this perspective, the dimension reflects the SQ as reliable, responsive, assurance, tangibles, and empathy. Reliability of the appraisal results to the lowering of the total cost of the IT operation. Process response in IT incident must be in acceptable responsive time, as it will affect the user's expectation towards the service. The assurance of the services confirms and verifies the expectation of users towards the services. Tangible products in hardware support documentation maintain the services in systematic and discipline in troubleshooting systems. Empathy refers to the communication between the IT service support in understanding customers' needs and attention to IT incidents.

Table 2: IT Frameworks Judgement

\begin{tabular}{|c|c|c|c|}
\hline & ITIL Ver.3 & COBIT 5 & CMMI-SVC \\
\hline Originated & $\begin{array}{c}\text { Open } \\
\text { Geospatial } \\
\text { Consortium } \\
\text { (OGC) }\end{array}$ & $\begin{array}{l}\text { Information } \\
\text { Systems } \\
\text { Audit and } \\
\text { Control } \\
\text { Association } \\
\text { (ISACA) }\end{array}$ & $\begin{array}{c}\text { Software } \\
\text { Engineering } \\
\text { Institute } \\
\text { (SEI) }\end{array}$ \\
\hline Emphasis & Service & Service & Service \\
\hline $\begin{array}{c}\text { Incident } \\
\text { Management } \\
\text { (IM) }\end{array}$ & Yes & Yes & Yes \\
\hline $\begin{array}{l}\text { Procedure } \\
\text { Involved }\end{array}$ & $\begin{array}{l}\text { Incident } \\
\text { Management }\end{array}$ & $\begin{array}{l}\text { Service } \\
\text { Requests } \\
\text { and } \\
\text { Incidents }\end{array}$ & $\begin{array}{l}\text { Incident } \\
\text { Resolution } \\
\text { and } \\
\text { Prevention }\end{array}$ \\
\hline $\begin{array}{l}\text { Number of } \\
\text { Processes }\end{array}$ & 26 & 37 & 24 \\
\hline
\end{tabular}

According to Table 2, all three frameworks appear to consume information on incident management (IM) that enable them to propose appropriate frameworks for input on the ITHS model. 
The ITIL is consisted of 26 processes; COBIT 5 is consisted of 37 processes, and the CMM SVC involves 24 processes. Akk processes involved in the IT framework and are very generic and very intricate. Only selected process requires the ITHS model development to focus on IT hardware only.

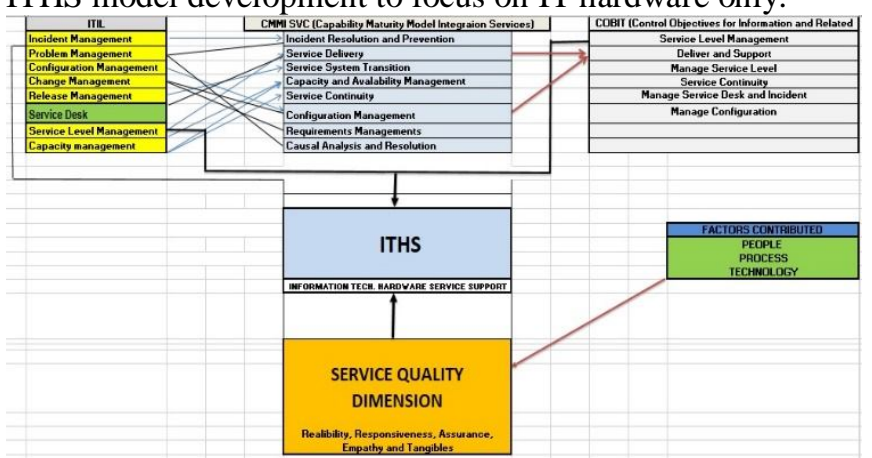

Figure 1: Similarities or overlap services or components of the three IT Framework. Develop for this research study.

(Merging process)

Figure 1 shows the affiliation between the selected IT Framework (ITIL, CMMI-SVC, and COBIT 5). It can be seen that the processes and components show similarities of work processes but were given different names. The merging process includes the similars components to be merged into one element. Elements from each three IT Framework were used on the ITHS element. The SQ dimension used to measure the effectiveness of the ITHS element. People, process, and technology were the three factors that contributed to the SQ dimension reflected in the ITHS. Table 3 depicts the development of similarities between the three IT Frameworks.

Table 3: Component and process from the IT framework.

\begin{tabular}{|c|c|c|}
\hline ITIL & CMMI-SVC & COBIT 5 \\
\hline Service & Define Process: & $\begin{array}{c}\text { Deliver } \\
\text { service and } \\
\text { support: }\end{array}$ \\
$\begin{array}{c}\text { Incident } \\
\text { Management } \\
\text { Event } \\
\text { management } \\
\text { Problem } \\
\text { Management }\end{array}$ & $\begin{array}{c}\text { Incident } \\
\text { Resolution and } \\
\text { Prevention }\end{array}$ & $\begin{array}{c}\text { Manage } \\
\text { service } \\
\text { requests and } \\
\text { incidents. }\end{array}$ \\
\hline
\end{tabular}

Table 3 developed to resolve the similarities occurred in the processes of ITIL, CMMI SVC, and COBIT 5. It also illustrates the combination of the IT framework processess (ITIL, CMMI SVC, COBIT 5). Synthesis of processes from the ITIL, CMMI SVC, and COBIT 5 was implemented. Due to the similarities or overlap process of each framework, the complementary and techniques were similar. Complementarity was used to refer to models that use elements of other models to maximize their quality. For example, activity conducted to classify the linked components between two models can be referred to as summation or mapping. The previous discussion are related to the independent variable while the dependent variables are the Service Quality dimension components which are reliability, assurance, responsiveness, empathy, and tangible. Measurement services reflect the improvement to the Service Quality in ITHS.

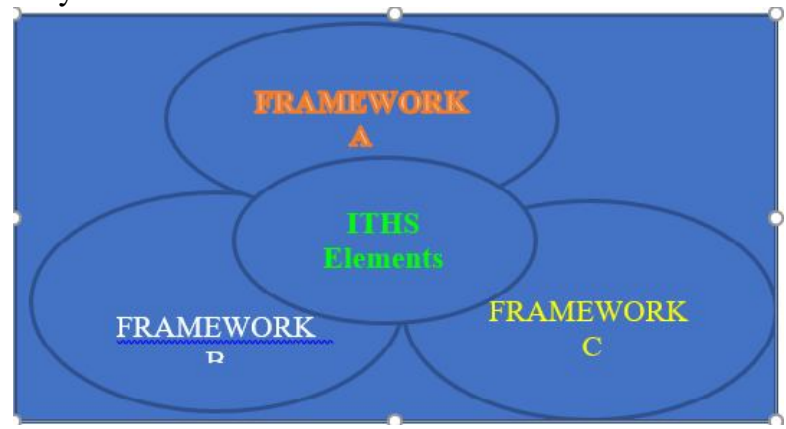

Figure 2: Theoretical Framework of IT Hardware Services (ITHS) based on the IT Framework Component.

Figure 2 depicts thetheoretical framework proposed for the ITHS element. Every framework (A, B, C) has its component and process. Framework Arepresents the ITIL framework. While Framework B represents the CMMI SVC and, finally, Framework $\mathrm{C}$ represents theCOBIT 5 framework. The similar processes existed in each component ofFramework (A, B, C) contributed to the ITHS elements.

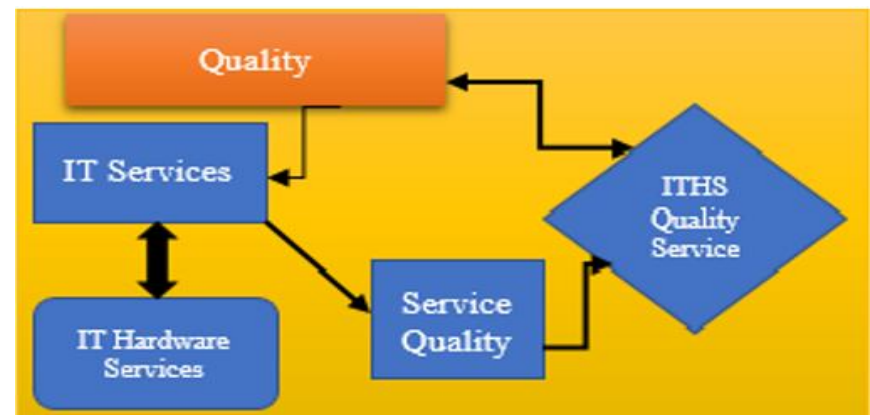

Figure 3: Quality relationship to the ITHS Quality service.

Figure 3 illustrates the relationship between quality that reflects the IT services subset to the IT hardware services (designed for this study). Every incident is to be directly reported to the IT service. The IT services are divided into various categories, namely, hardware, software, or the network system. Every incident must be resolved in response time, as stated in department policies. The time to resolve the incident request reflects the Service Quality of the IT services as customers are the ones to rate their satisfaction towards the service. Users satisfaction and interpretation in quality service is the essential element that reflects the overall quality of the organization.

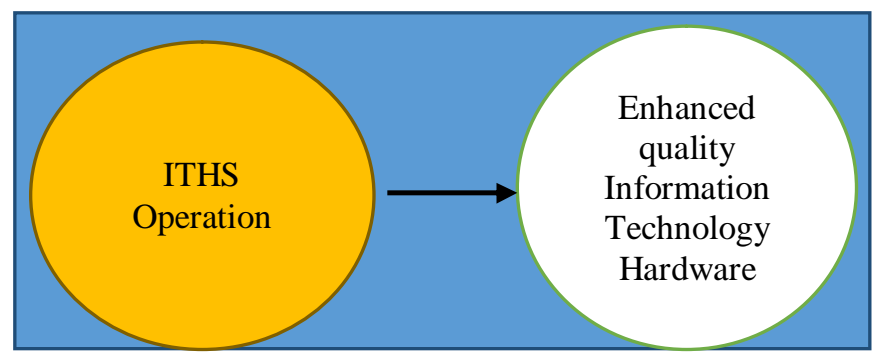

Figure 4: General Conceptual model (Sources: Developed for this research area) 
Figure 4 demonstrates the general conceptual framework model in the ITHS Operation. The purpose of improving the quality services of the ITHS is to enhance customer satisfaction, response time, and return on investment (ROI) to the company or organization itself, especially on daily IT routine services.

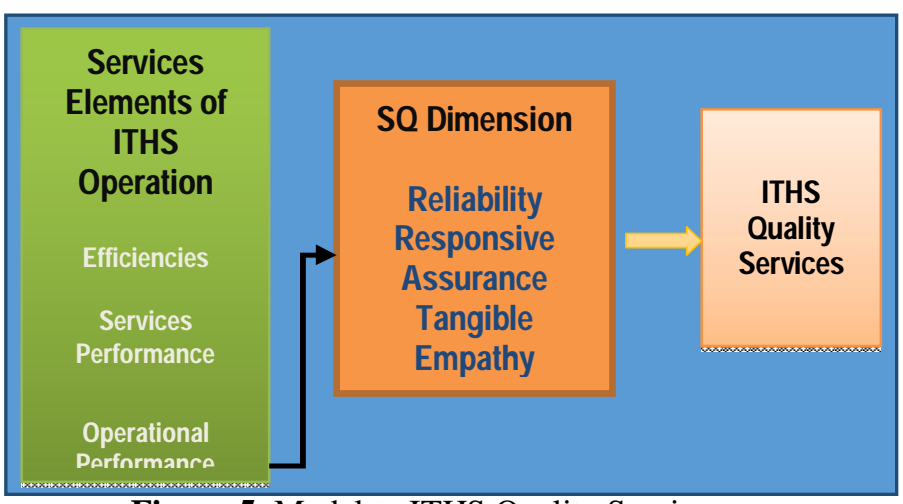

Figure 5: Model to ITHS Quality Services.

Figure 5 providesthe illustration model to ITHS quality services. Although it is not finalized, this illustrationdemonstrates the similarities process of the three selected IT frameworks (ITIL, COBIT, and CMMI SVC). Service elements from the ITHS operation such as efficiencies, service performance, and operational performance measure to the Service Quality (SQ) dimension reflects the ITHS Quality services. The elements from the ITHS strengthen the IS Theory on Technology, Organization, and Environment [70]. The technological context encompasses all technologies that are applicable to the organisation. The organisational perspective refers to the characteristics and resources of the firm, including the link between the staff, intra-firm communication procedures, the size of the firm, and the number of scarce resources. Whereas, the environmental context includes the structure of the industry, the presence or absence of technology service providers, and the business environment. [71][72][73].

\section{REFERENCES}

1. J. Aguiar, R. Pereira, J. B. Vasconcelos, and I. Bianchi, "An overlapless incident management maturity model for multi-framework assessment (ITIL, COBIT, CMMI-SVC),'Interdiscip. J. Information, Knowledge, Manag., 2018.

2. S. Sahney, D. K. Banwet, and S. Karunes, "A SERVQUAL and QFD approach to total quality education: A student perspective,'Int. J. Product. Perform. Manag., 2004.

3. P. Kotler and F. Bliemel, Marketing-Management: Analyse, Planung und Verwirklichung. 2001.

4. S. Lagrosen, R. Seyyed-Hashemi, and M. Leitner, "Examination of the dimensions of quality in higher education," Qual. Assur. Educ., 2004.

5. D. A. Garvin, "WHAT DOES 'PRODUCT QUALITY' REALLY MEAN?,"Sloan Manage. Rev., 1984.

6. T. G. Gebreegziabher, "June, 2018 Addis Ababa
,Ethiopia," p. 2018, 2018.

7. C. Advantage and I. A. Elshaer, "The Relationship between Quality Management and By :," no. July, pp. 1-365, 2012.

8. B. W. Tuchman, "The decline of quality," $N$. $Y$. Times Mag., 1980.

9. A. V. Feigenbaum and D. S. Feigenbaum, "What quality means today," MIT Sloan Management Review. 2005.

10. T. Levitt, "Production-Line Approach to Service," in The Roots of Logistics, 2012.

11. L. A. Crosby, K. R. Evans, and D. Cowles, 'Relationship Quality in Services Selling: An Interpersonal Influence Perspective,'J. Mark., 1990.

12. J. M. Juran, “Juran on planning for quality," New york Free Press, 1988.

13. K. B. Leffler, "Ambiguous changes in product quality," Am. Econ. Rev., 1982.

14. G. Taguchi, S. Chowdhury, and Y. Wu, Taguchi's Quality Engineering Handbook. 2007.

15. J. Ryall and J. Kruithof, "The quality systems handbook," p. 313, 2001.

16. M. Abdous, "E-learning quality assurance: A process-oriented lifecycle model,"Qual. Assur. Educ., 2009.

17. F. Bilika, M. Safari, and S. Mansori, "Review of Empirical Studies of Service Quality, Customer Satisfaction, and Loyalty,"J. Mark. Manag. Consum. Behav., 2016.

18. V. A. Zeithaml, "Service quality, profitability, and the economic worth of customers: What we know and what we need to learn," J. Acad. Mark. Sci., 2000.

19. A. Parasuraman, L. L. Berry, and V. A. Zeithaml, "More on improving service quality measurement,'J. Retail., 1993.

20. a Parasuraman, V. a Zeithaml, and L. L. Berry, "SERQUAL: A Multiple-Item scale for Measuring Consumer Perceptions of Service Quality,'Journal of Retailing. 1988.

21. A. Parasuraman, V. A. Zeithaml, and L. L. Berry, "A Conceptual Model of Service Quality and Its Implications for Future Research," J. Mark., 1985.

22. A. Akbaba et al., "Reliability of SERVQUAL in the Hotel Sector of Pune City: An Empirical Investigation," J. Retail., 2014.

23. M. J. Bitner, V. A. Zeithaml, and D. D. Gremler, "Technology's Impact on the Gaps Model of Service Quality," 2010.

24. S. N. R. Sakrani, S. A. Wahab, N. J. A. Y. Norazira Abas, and S. N. A. M. Rodzi, "Adaptive of SERVQUAL Model in Measuring Customer Satisfaction towards Service Quality Provided by Bank Islam Malaysia Berhad (BIMB) in Malaysia,'Int. J. Bus. Soc. Sci., vol. 4, no. 10, pp. 189-198, 2013.

25. S. Cronin, J., Taylor, "Measuring Service Quality: A Reexamination and Extension.: Sistema de 
descoberta para FCCN,"J. Mark., 1992.

26. Y. Lu and K. (Ram) Ramamurthy, "Improving Decision Making in Organisations," Manag. Inf. Syst. Q., vol. 35, no. 4, pp. 931-954, 2011.

27. V. A. Zeithaml, L. L. Berry, and A. Parasuraman, "The behavioral consequences of service quality,"J. Mark., 1996.

28. H. Baber, "Service quality perception of customers -A study of Toyota motors in India,"Organ. Mark. Emerg. Econ., vol. 9, no. 2, pp. 311-323, 2018.

29. U. Kingdom, "Assuring Quality in Higher Education: The New Zealand Experience,'J. Institutional Res., vol. 14, no. 2, pp. 60-72, 2009.

30. F. Abdullah, "Measuring service quality in higher education: HEdPERF versus SERVPERF,'Mark. Intell. Plan., 2006.

31. F. Abdullah, 'HEdPERF versus SERVPERF: The quest for ideal measuring instrument of service quality in higher education sector,'Qual. Assur. Educ., 2005.

32. N. El Saghier and D. Nathan, "Service Quality Dimensions and Customers, Satisfactions of Banks in Egypt,'Proc. 20th Int. Bus. Res. Conf., 2013.

33. N. A. S. Abdullah, N. L. M. Noor, and E. N. M. Ibrahim, "Information technology service management (ITSM): Contributing factors to it service disruptions - A case of Malaysia public service agencies," Proc. - Pacific Asia Conf. Inf. Syst. PACIS 2014, 2014.

34. D. Spath, W. Bauer, and C.-P. Praeg, "IT Service Quality Management," in Quality Management for IT Services, 2011.

35. J. J. James, K. Gary, and M. C. Suzzane, "A note on SERVQUAL reliability and validity in information system service quality measurement," Decis. Sci., 2000.

36. L. F. Pitt, R. T. Watson, and C. B. Kavan, "Service quality: A measure of information systems effectiveness," MIS Q. Manag. Inf. Syst., 1995.

37. W. H. DeLone and E. R. McLean, "The DeLone and McLean model of information systems success: A ten-year update," in Journal of Management Information Systems, 2003.

38. N. Urbach and B. Müller, "The Updated DeLone and McLean Model of Information Systems Success," 2012.

39. A. L. I. Yazici, A. Mishra, and P. Kontogiorgis, "IT Service Management (ITSM) Education and Research: Global View,'Int. J. Eng. Educ., vol. 31, no. 4, pp. 1071-1080, 2015.

40. S. Dhingra, "Managing the internal IT service quality in public sector banks of India,'Int. J. Bus. Inf. Syst., vol. 19, no. 4, pp. 403-418, 2015.

41. H. Kang and G. Bradley, "Measuring the performance of IT services: An assessment of SERVQUAL," Int. J. Account. Inf. Syst., 2002.

42. A. L. P. Freitas and H. G. Costa, "Development and Testing of a Multi-Criteria Approach to the
Assessment of Service Quality : An Empirical Study in," Int. J. Manag., 2012.

43. J. Peppard, "Managing IT as a portfolio of services,'Eur. Manag. J., 2003.

44. J. J. Jiang, G. Klein, and S. M. Crampton, "A Note on SERVQUAL Reliability and Validity in Information System Service Quality Measurement,'Decis. Sci., 2000.

45. W. J. Kettinger and C. C. Lee, 'Pragmatic perspectives on the measurement of information systems service quality,"MIS $Q$. Manag. Inf. Syst., 1997.

46. N. F. Al-Mushasha and A. B. Nassuora, "Factors determining e-learning service quality in jordanian higher education environment," $J$. Appl. Sci., 2012. https://doi.org/10.3923/jas.2012.1474.1480

47. W. W. Chin and P. A. Todd, "On the use, usefulness, and ease of use of structural equation modeling in mis research: A note of caution," MIS Q. Manag. Inf. Syst., 1995.

48. X. Chen and P. Sorenson, "Towards TQM in IT services,'Proc. 2007 Work. Autom. Serv. Qual. WRASQ '07, Held Int. Conf. Autom. Softw. Eng. ASE 2007, no. November, pp. 42-47, 2007.

49. H. Wang, S. Sun, Y. Huang, and S. Cheng, "An ITIL-based IT service management model for garment enterprises," Proc. Int. Conf. Inf. Manag. Int. Conf. Inf. Manag. Innov. Manag. Ind. Eng. ICIII 2008, vol. 2, pp. 47-51, 2008.

50. G. Wang, W. Zhang, C. Huang, and Z. Chen, "Service Availability Monitoring and Measurement Based on Customer Perception," in Proceedings of the IEEE International Conference on Software Engineering and Service Sciences, ICSESS, 2019.

51. M. Lepmets, E. Ras, and A. Renault, "A quality measurement framework for IT services,"Proc. 2011 Annu. SRII Glob. Conf. SRII 2011, no. March, pp. 767-774, 2011.

52. A. Shrestha, A. Cater-steel, M. Toleman, and W. Tan, “U6 h,” vol. 15, no. 3, pp. 9-9, 2014.

53. S. Galup, R. Dattero, J. J. Quan, and S. Conger, 'Information Technology Service Management : An Emerging Area for Academic Research and Pedagogical Development,'Spec. Interes. Gr. Comput. Pers. Res. Annu. Conf., vol. April, pp. 46-52, 2007.

54. S. Cronholm and N. Salomonson, "Measures that matters: Service quality in IT service management,'Int. J. Qual. Serv. Sci., vol. 6, no. 1, pp. 60-76, 2014.

55. S. Alter, "Seeking synergies between four views of service in the is field," in 14th Americas Conference on Information Systems, AMCIS 2008, 2008.

56. A. Ghildyal and E. Chang, "IT Governance and Benefit Models: Literature Review and Proposal of aNovel Approach," Int. J. e-Education, e-Business, e-Management e-Learning, 2017.

57. L. Raymond, F. Bergeron, A.-M. Croteau, and S. 
Uwizeyemungu, "Determinants and outcomes of IT governance in manufacturing SMEs: A strategic IT management perspective," Int. J. Account. Inf. Syst., 2019. https://doi.org/10.1016/j.accinf.2019.07.001

58. P. Weil and J. W. Ross, "IT Governance: How Top Performers Manage IT,'Int. J. Eletronic Gov. Res., 2005.

59. M. Khouja, I. B. Rodriguez, Y. Ben Halima, and S. Moalla, "IT governance in higher education institutions: A systematic literature review,'Int. J. Hum. Cap. Inf. Technol. Prof., vol. 9, no. 2, pp. 52-67, 2018.

60. T. Sethibe, J. Campbell, and C. McDonald, "IT governance in public and private sector organizations: Examining the differences and defining future research directions," in ACIS 2007 Proceedings - 18th Australasian Conference on Information Systems, 2007.

61. S. K. Somansa, H. J. Lee, and C. S. Leem, "Applying the ISO17799 Baseline Controls as a Security Engineering Principle under the Sarbanes-Oxley Act," in International Conference of Computational Methods in Sciences and Engineering 2004 (ICCMSE 2004), 2019.

62. M. Nicho Robert and S. Khan, "IT Governance Measurement Tools and its Application in IT-Business Alignment,'J. Int. Technol. Inf. Manag., 2017.

63. R. Weber, "Design-science research," in Research Methods: Information, Systems, and Contexts: Second Edition, 2018.

64. K. Peffers, T. Tuunanen, and B. Niehaves, "Design science research genres: introduction to the special issue on exemplars and criteria for applicable design science research,'European Journal of Information Systems. 2018.

65. S. Gregor and A. R. Hevner, "POSITIONING AND P RESENTING D ESIGN S CIENCE Types of Knowledge in Design Science Research,"MIS Q., 2013.

66. K. De Maere and S. De Haes, "Is the design science approach fit for IT governance research?," in Proceedings of the European Conference on Research Methods in Business and Management Studies, 2017.

67. J. Venable, J. Pries-Heje, and R. Baskerville, "FEDS: A Framework for Evaluation in Design Science Research," European Journal of Information Systems. 2016.

68. 68. Widjajarto, M. Lubis, and M. K. Rizal Syahputra, 'Optimization performance management with FCAPS and ITILv3: Opportunities and obstacles,'Indones. J. Electr. Eng. Comput. Sci., 2019.

69. M. H. Ghahramani, M. Zhou, and C. T. Hon, "Toward cloud computing QoS architecture: Analysis of cloud systems and cloud services," IEEE/CAA J. Autom. Sin., 2017.

70. L. G. Tornatzky and M. Fleischer, The Process of
Technology Innovation. 1990.

71. S. Kasiewicz, "New trends in the system regulating the market of bank services,"Kwart. Nauk o Przedsiębiorstwie, 2017. https://doi.org/10.5604/01.3001.0010.7450

72. H. Ahmadi et al., "Organizational Factors Affecting the Adoption of a Technological Innovation: A Study of the Hospital Information System (HIS)," in 2019 5th International Conference on Web Research, ICWR 2019, 2019.

73. P. D. Collins, J. Hage, and F. M. Hull, "Organizational and Technological Predictors of Change in automaticity,”Acad. Manag. J., 1988. 